\title{
Negative Effect of Ellagic Acid on Cytosolic pH Regulation and Glycolytic Flux in Human Endometrial Cancer Cells
}

\author{
Khalid N. M. Abdelazeem ${ }^{\mathrm{a}, \mathrm{c}} \quad$ Yogesh Singh $^{\mathrm{a}} \quad$ Florian Lang $^{\mathrm{a}, \mathrm{b}} \quad$ Madhuri S. Salker $^{\mathrm{a}}$ \\ aDepartment of Internal Medicine III, Eberhard Karls University of Tuebingen, Tuebingen, ${ }^{b}$ Department \\ of Molecular Medicine II, Medical Faculty, Heinrich Heine University, Duesseldorf, Germany; 'Radiation \\ Biology Research Department, National Center for Radiation Research and Technology, Atomic Energy \\ Authority, Cairo, Egypt
}

Key Words

Glycolysis $\bullet$ Cytosolic pH regulation $\bullet \mathrm{Na}^{+} / \mathrm{H}^{+}$exchanger $\bullet \mathrm{NHE1} \cdot$ Tumor cells

\begin{abstract}
Background/Aims: Key properties of tumor cells include enhanced glycolytic flux with excessive consumption of glucose and formation of lactate. As glycolysis is highly sensitive to cytosolic $\mathrm{pH}$, maintenance of glycolysis requires export of $\mathrm{H}^{+}$ions, which is in part accomplished by $\mathrm{Na}^{+} / \mathrm{H}^{+}$exchangers, such as NHE1. The carrier is sensitive to oxidative stress. Growth of tumor cells could be suppressed by the polyphenol Ellagic acid, which is found in various fruits and vegetables. An effect of Ellagic acid on transport processes has, however, never been reported. The present study thus elucidated an effect of Ellagic acid on cytosolic $\mathrm{pH}(\mathrm{pHi}), \mathrm{NHE1}$ transcript levels, NHE1 protein abundance, $\mathrm{Na}^{+} / \mathrm{H}^{+}$exchanger activity, and lactate release. Methods: Experiments were performed in Ishikawa cells without or with prior Ellagic acid $(20 \mu \mathrm{M})$ treatment. NHE1 transcript levels were determined by qRTPCR, NHE1 protein abundance by Western blotting, $\mathrm{pH}_{\mathrm{i}}$ utilizing $\left(2^{\prime}, 7^{\prime}\right.$-bis-(2-carboxyethyl)5-(and-6)-carboxyfluorescein [BCECF] fluorescence, $\mathrm{Na}^{+} / \mathrm{H}^{+}$exchanger activity from $\mathrm{Na}^{+}$ dependent realkalinization after an ammonium pulse, cell volume from forward scatter in flow cytometry, reactive oxygen species (ROS) from $2^{\prime}, 7^{\prime}$-dichlorodihydrofluorescein fluorescence, glucose uptake utilizing 2-(N-(7-nitrobenz-2-oxa-1,3-diazol-4-yl)amino)-2-deoxyglucose, and lactate concentration in the supernatant utilizing a colorimetric $(570 \mathrm{~nm}) /$ fluorometric enzymatic assay. Results: A 48 hour treatment with Ellagic acid $(20 \mu \mathrm{M})$ significantly decreased NHE1 transcript levels by $75 \%$, NHE1 protein abundance by $95 \%$, pHi from $7.24 \pm 0.01$ to $7.02 \pm 0.01, \mathrm{Na}^{+} / \mathrm{H}^{+}$exchanger activity by $77 \%$, forward scatter by $10 \%$, ROS by $82 \%$, glucose uptake by $58 \%$, and lactate release by $15 \%$. Conclusion: Ellagic acid $(20 \mu \mathrm{M})$ markedly downregulates ROS formation and NHE1 expression leading to decreased $\mathrm{Na}^{+} / \mathrm{H}^{+}$exchanger activity, $\mathrm{pHi}$, glucose uptake and lactate release in endometrial cancer cells. Those effects presumably contribute to reprogramming and growth inhibition of tumor cells.
\end{abstract}




\section{Cellular Physiology Cell Physiol Biochem 2017;41:2374-2382 \begin{tabular}{l|l} 
DOI: 10.1159/000475655 & Ond Biochemistry 2017 The Author(s). Published by S. Karger AG, Basel \\
Published onnine: April 27, 2017 & $\begin{array}{l}\text { www.karger.com/cpb } \\
\text { and }\end{array}$
\end{tabular} Abdelazeem et al.: Effect of Ellagic Acid on Endometrial Cancer Cells}

\section{Introduction}

Endometrial cancer is a leading cause of cancer-related death in women and the incidence is rising steadily in almost all countries [1]. Development and progression of endometrial cancer is influenced by genetic mutations and epigenetic changes in various cancer-related genes as well as disordered hormone levels [2]. Prophyllaxis and treatment of cancer could be accomplished by Ellagic acid (EA) [3-5], a naturally occurring phenolic constituent of ellagitannins in grapes, nuts, strawberries, blackcurrent, raspberries, green tea, and pomegranate [6]. EA treatment is a new and highly effective strategy in reducing carcinogenesis [7, 8]. EA exerts anticancer effects through its antiproliferative and proapoptotic actions [5]. EA further provides neuroprotection in Parkinson's Disease [9] and favourably influences the clinical course of Hepatitis C virus infection [10] and several chronic diseases, such as diabetes [11].

EA can act through multiple pathways and can be used as a dietary agent for preventing and treating many common forms of cancer $[7,8]$. Through the action of human colonic microflora, EA is partially converted into metabolites, including hydroxy-6H-benzopyran6-one derivatives, primarily urolithin A (UA) [12]. Both, EA and urolithins enter the circulation. Recent studies based on in vitro testing have shown preliminary evidence on the anti-inflammatory, anticarcinogenic, antiglycolytic, antioxidant, and antimicrobial effects of urolithins $[5,6,12]$.

Typical properties of cancer cells include strong stimulation of glycolysis with the respective formation of lactate $[13,14]$. A prerequisite for unhindered glycolytic flux is avoidance of cytosolic acidification, which inhibits the rate limiting enzymes of glycolysis [15]. Mechanisms counteracting cytosolic acidification of tumor cells include activation of $\mathrm{Na}^{+} / \mathrm{H}^{+}$exchangers such as NHE1 $[13,16]$. NHE1 expression is sensitive to oxidative stress [17]. Besides its impact on glycolysis, the carrier participates in cell volume regulation [18].

The present study explored whether Ellagic acid $\left(20 \mu \mathrm{M}\right.$; EA) affects cytosolic $\mathrm{pH}, \mathrm{Na}^{+} /$ $\mathrm{H}^{+}$exchanger NHE1 expression, $\mathrm{Na}^{+} / \mathrm{H}^{+}$exchanger activity, oxidative stress, cell volume, cellular glucose uptake and glycolytic flux in human endometrial Ishikawa cells.

\section{Materials and Methods}

\section{Cell Culture}

Ishikawa cells (well differentiated endometrial carcinoma cell model) were cultured in DMEM/F12 without phenol red media, containing 10\% fetal calf serum (FCS), 1\% antibiotic/antimycotic solution and $0.25 \%$ L-Glutamine (Invitrogen, Germany). Cells were treated as described with Ellagic acid (\#E2250 $20 \mu \mathrm{M}$ Sigma, Germany) for $48 \mathrm{~h}$.

\section{Quantitative Real-time PCR}

Total RNA was extracted from Ishikawa cultures using Trizol (Invitrogen) based on a phenolchloroform extraction protocol. Equal amounts of total RNA ( $2 \mu \mathrm{g})$ were reverse transcribed by using the Superscript III First-Strand synthesis system for RT-PCR (Invitrogen) using an oligo dT primer. The resulting first-strand cDNA was diluted 1:20 with distilled water and used as template in qRT-PCR analysis. L19 was used to normalize for variances in input cDNA. Detection of gene expression was performed with KappaFast -SYBR Green (VWR-Peqlab, Germany) and Quantitative RT-PCR was performed on a BioRad iCycler $\mathrm{iQ}^{\mathrm{TM}}$ Real-Time PCR Detection System (Bio-Rad Laboratories, Germany). The expression levels of the samples are provided as arbitrary units defined by the $\Delta \Delta \mathrm{C}_{\mathrm{T}}$ method. All measurements were performed in triplicate. Melting curve analysis and agarose gel electrophoresis confirmed amplification specificity.

Primer Sequence

NHE1 forward (5'-3'):ACCTGGTTCATCAACAAGTTCCG

L19 forward (5'-3'): GCAGCCGGCGCAAA

reverse (5'-3'): GCGGAAGGGTACAGCCAAT 


\section{Cellular Physiology Cell Physiol Biochem 2017;41:2374-2382 and Biochemistry Published onlIne: April 27, $2017 \quad \begin{aligned} & \text { DOI: 10.1159/000475655 } 2017 \text { The Author(s). Published by S. Karger AG, Basel } \\ & \text { www.karger.com/cpb }\end{aligned}$ \\ Abdelazeem et al.: Effect of Ellagic Acid on Endometrial Cancer Cells}

Western blotting

For determination of NHE1 protein abundance, whole cell protein extracts were prepared by lysing cells in RIPA buffer. Protein yield was quantified using the Bio-Rad DC protein assay kit (Bio-Rad, USA). Equal amounts of proteins (30 $\mu \mathrm{g}$ ) were separated on $10 \%$ sodium dodecyl sulfate-polyacrylamide (SDS) gel before electrotransfer onto the PVDF membrane (Amersham Biosciences, Germany). Nonspecific binding sites were blocked by 1 hour incubation with $5 \%$ nonfat dry milk in Tris-buffered saline with $1 \%$ Tween (TBS; $130 \mathrm{mmol} / \mathrm{L} \mathrm{NaCl}, 20 \mathrm{mmol} / \mathrm{L}$ Tris, pH7.6 and 1\% Tween). NHE1 was identified by primary antibodies against human NHE1 (1:1000, \#gtx85047, Genetex) and antibody against GAPDH (1:1000, \#8884, Cell Signalling, The Netherlands) served as a loading control. For detection, a secondary anti-rabbit IgG antibody conjugated with horseradish peroxidase (HRP) (1:2000, Cell Signaling, The Netherlands) or secondary anti-mouse IgG antibody conjugated with HRP (1:2000, GE Healthcare,UK) was used. Protein complexes were visualized with a chemiluminescent detection kit (GE Healthcare). All experiments were performed in 3 or more cell cultures. Bands were quantified with ImageJ Software.

\section{Intracellular $\mathrm{pH}$}

For digital imaging of cytosolic $\mathrm{pH}\left(\mathrm{pH}_{\mathrm{i}}\right)$, the cells were incubated in a HEPES-buffered Ringer solution containing $10 \mu \mathrm{M}$ BCECF-AM (2',7'-Bis-(2-Carboxyethyl)-5-(and-6)-Carboxyfluorescein, Acetoxymethyl Ester, Molecular Probes, Leiden, The Netherlands) for 15 min at $37^{\circ} \mathrm{C}$ [19-22]. After loading, the chamber was flushed for 5 min with Ringer solution to remove any deesterified dye. The perfusion chamber was mounted on the stage of an inverted microscope (Axiovert 135, Zeiss, Germany), which was used in the epifluorescence mode with a $40 \mathrm{x}$ oil immersion objective (Neoplan, Zeiss). BCECF was successively excited at 490/10 $\mathrm{nm}$ and $440 / 10 \mathrm{~nm}$, and the resultant fluorescent signal was monitored at 535/10 nm using an intensified charge-coupled device camera (Proxitronic, Germany) and specialized computer software (Metafluor, USA). Between 10-20 cells were outlined and monitored during the course of the measurements. The results from each cell were averaged and taken for final analysis. Intensity ratio (490/440) data were converted into $\mathrm{pH}_{\mathrm{i}}$ values using the high- $\mathrm{K}^{+} /$nigericin calibration technique [23]. To this end, the cells were perfused at the end of each experiment for 5 minutes with standard high- $\mathrm{K}^{+} /$ nigericin $(10 \mu \mathrm{g} / \mathrm{ml})$ solution ( $\mathrm{pH} 7.0)$. The intensity ratio data thus obtained were converted into $\mathrm{pH}$ values using the $\mathrm{r}_{\text {max }}, \mathrm{r}_{\text {min' }}, \mathrm{pK}_{\mathrm{a}}$ values previously generated from calibration experiments to generate a standard nonlinear curve ( $\mathrm{pH}$ range 5 to 8.5).

For acid loading, cells were transiently exposed to a solution containing $20 \mathrm{mM} \mathrm{NH}_{4} \mathrm{Cl}$ leading to initial alkalinization of cytosolic $\mathrm{pH}\left(\mathrm{pH}_{\mathrm{i}}\right)$ due to entry of $\mathrm{NH}_{3}$ and binding of $\mathrm{H}^{+}$to form $\mathrm{NH}_{4}^{+}$[19]. The acidification of cytosolic $\mathrm{pH}$ upon removal of ammonia allowed calculating the mean intrinsic buffering power $(ß)$ of the cells [24]. Assuming that $\mathrm{NH}_{4}^{+}$and $\mathrm{NH}_{3}$ are in equilibrium between cytosolic and extracellular fluid and that ammonia leaves the cells as $\mathrm{NH}_{3}$ :

$ß=\Delta\left[\mathrm{NH}_{4}^{+}\right]_{\mathrm{i}} / \Delta \mathrm{pH}_{\mathrm{i}}$,

where $\Delta \mathrm{pH}_{\mathrm{i}}$ is the decrease of cytosolic $\mathrm{pH}\left(\mathrm{pH}_{\mathrm{i}}\right)$ following ammonia removal and $\Delta\left[\mathrm{NH}_{4}^{+}\right]_{\mathrm{i}}$ is the decrease of cytosolic $\mathrm{NH}_{4}{ }^{+}$concentration, which is identical to the concentration of $\left[\mathrm{NH}_{4}{ }^{+}\right]_{\mathrm{i}}$ immediately before the removal of ammonia. The $\mathrm{pK}$ for $\mathrm{NH}_{4}^{+} / \mathrm{NH}_{3}$ is 8.9 [25] and at an extracellular $\mathrm{pH}\left(\mathrm{pH}_{0}\right)$ of 7.4 the $\mathrm{NH}_{4}{ }^{+}$concentration in extracellular fluid $\left(\left[\mathrm{NH}_{4}^{+}\right]_{0}\right)$ is $19.37\left[20 /\left(1+10^{\mathrm{pHo}-\mathrm{pK}}\right)\right]$. The intracellular $\mathrm{NH}_{4}^{+}$ concentration $\left(\left[\mathrm{NH}_{4}\right]_{\mathrm{i}}\right)$ was calculated from:

$\left[\mathrm{NH}_{4}\right]_{\mathrm{i}}=19.37 \cdot 10^{\mathrm{pHo}-\mathrm{pHi}}$.

The calculation of the buffer capacity required that $\mathrm{NH}_{4}^{+}$exits completely. After the initial decline, $\mathrm{pH}_{\mathrm{i}}$ indeed showed little further change in the absence of $\mathrm{Na}^{+}$, indicating that there was no relevant further exit of $\mathrm{NH}_{4}^{+}$.

NHE1 activity was measured as the slope of the first 5 minutes of recovery from acidification and was expressed as $\Delta \mathrm{pH}_{\mathrm{i}}$ per minute, which could be applied to all measured cells.

The solutions were composed of (in mM): standard Hepes: $115 \mathrm{NaCl}, 5 \mathrm{KCl}, 1 \mathrm{CaCl}_{2}, 1.2 \mathrm{MgSO}_{4}, 2$ $\mathrm{NaH}_{2} \mathrm{PO}_{4} 10$ glucose, 32.2 Hepes; sodium free Hepes: $132.8 \mathrm{NMDGCl}, 3 \mathrm{KCl}, 1 \mathrm{CaCl}_{2}, 1.2 \mathrm{MgSO}_{4^{\prime}}, 2 \mathrm{KH}_{2} \mathrm{PO}_{4^{\prime}}$ 32.2 Hepes, 10 mannitol, 10 glucose (for sodium free ammonium chloride $10 \mathrm{mM}$ NMDG and mannitol were replaced with $20 \mathrm{mM} \mathrm{NH}_{4} \mathrm{Cl}$ ); high $\mathrm{K}^{+}$for calibration: $105 \mathrm{KCl}, 1 \mathrm{CaCl}_{2}, 1.2 \mathrm{MgSO}_{4}, 32.2 \mathrm{Hepes}, 10$ mannitol, $5 \mu \mathrm{M}$ nigericin. The $\mathrm{pH}$ of the solutions was titrated to 7.4 or 7.0 with $\mathrm{HCl} / \mathrm{NaOH}, \mathrm{HCl} / \mathrm{NMDG}$ and $\mathrm{HCl} / \mathrm{KOH}$, respectively, at $37^{\circ} \mathrm{C}$. 


\section{Cellular Physiology Cell Physiol Biochem 2017;41:2374-2382 \begin{tabular}{l|l} 
and Biochemistry Published onlIne: April 27, 2017 & $\begin{array}{l}\text { C) } 2017 \text { The Author(s). Published by S. Karger AG, Basel } \\
\text { www.karger.com/cpb }\end{array}$
\end{tabular} \\ Abdelazeem et al.: Effect of Ellagic Acid on Endometrial Cancer Cells}

Lactate concentration in supernatant

Lactate concentration in the supernatant was determined utilizing a Lactate Assay Kit (Sigma \#MAK064), an enzymatic assay involving colorimetric $(570 \mathrm{~nm}) /$ fluorometric $(\lambda \mathrm{ex}=535 \mathrm{~nm} / \lambda \mathrm{em}=587$ $\mathrm{nm}$ ) measurements according to the manufacturer's protocol.

Determination of cellular glucose uptake and forward scatter in flow cytometry

After incubation under the respective experimental conditions, the cells were first washed with PBS and then detached with warm 0.25\% trypsin (\#25200-056, Invitrogen, Germany). Cells were collected after a brief centrifugation. The fluorescent glucose analogue 2-(N-(7-nitrobenz-2-oxa-1,3-diazol-4yl)amino)-2-deoxyglucose (\#N13195, 2-NBD-glucose; Invitrogen, Darmstadt, Germany) was used to measure the relative uptake of glucose by flow cytometry in a FACS Calibur (BD Biosciences, Germany). Cells $\left(1 \times 10^{6}\right)$ were incubated with 2-NBD-glucose $(10 \mu \mathrm{M})$ in phosphate buffered saline for 1 hour at $37^{\circ} \mathrm{C}$, subsequently washed twice in cold PBS and analyzed by flow cytometry at an excitation wavelength of $488 \mathrm{~nm}$ and an emission wavelength of $530 \mathrm{~nm}$. Changes in glucose uptake after inhibitor treatment were calculated as differences in geometric mean of the fluorescence. In parallel forward scatter was determined as a measure of cell volume.

Determination of reactive oxygen species in flow cytometry

After incubation under the respective experimental conditions, the cells were detached by $0.25 \%$ trypsin (as described above). Oxidative stress was determined utilizing 2',7'-dichlorodihydrofluorescein diacetate (DCFDA, \#D6883, Sigma). The cell suspension was washed in Ringer solution and stained with DCFDA in Ringer solution containing DCFDA at a final concentration of $10 \mu \mathrm{M}$. The cells were incubated at $37^{\circ} \mathrm{C}$ for $30 \mathrm{~min}$ in the dark and washed two times in Ringer solution. The DCFDA-loaded cells were resuspended in $200 \mu$ l Ringer solution and ROS-dependent fluorescence intensity was measured at an excitation wavelength of $488 \mathrm{~nm}$ and an emission wavelength of $530 \mathrm{~nm}$ on a FACS Calibur (BD Biosciences). Subsequently, the geometric mean of the DCFDA dependent fluorescence was determined.

\section{Statistics}

Data are provided as arithmetic means \pm SEM, $n$ represents the number of independent experiments. All data were tested for significance using Student's unpaired two-tailed $t$-test and only results with $P<0.05$ were considered statistically significant.

\section{Results}

The present study explored whether Ellagic acid (EA) influences cytosolic $\mathrm{pH}$ (pHi) regulation and glycolytic flux in Ishikawa cells. In a first step, the effect of a 48 hours exposure to EA $(20 \mu \mathrm{M})$ on the transcript levels of the $\mathrm{Na}^{+} / \mathrm{H}^{+}$exchanger isoform NHE1 was determined utilizing qRT-PCR. As illustrated in Fig. 1A, treatment of Ishikawa cells with EA $(20 \mu \mathrm{M}, 48$ hours) was followed by a significant decrease of the transcript levels encoding NHE1.

EA $(20 \mu \mathrm{M})$ similarly influences the protein expression of NHE1 in Ishikawa cells. As illustrated in Fig. 1B,C, treatment of Ishikawa cells with EA (20 $\mu \mathrm{M})$ for 48 hours was followed by a significant decline of NHE1 protein abundance.

In order to test, whether the down-regulation of NHE1 transcription and protein expression was paralleled by alterations of $\mathrm{Na}^{+} / \mathrm{H}^{+}$exchanger activity and cytosolic $\mathrm{pH}$ (pHi), pHi was estimated from BCECF fluorescence, and $\mathrm{Na}^{+} / \mathrm{H}^{+}$exchanger activity utilizing the ammonium pulse technique. As illustrated in Fig. 2A,B, EA treatment for 48 hours significantly decreased pHi. Addition of $20 \mathrm{mM} \mathrm{NH}_{4} \mathrm{Cl}$ replacing $\mathrm{NaCl}$ in the superfusate was followed by $\mathrm{NH}_{3}$ entry into the cells with subsequent transient cytosolic alkalinization due to binding of $\mathrm{H}^{+}$to $\mathrm{NH}_{3}$ to form $\mathrm{NH}_{4}^{+}$(Fig. 2A). Subsequent removal of $\mathrm{NH}_{4} \mathrm{Cl}$ was followed by cytosolic acidification due to $\mathrm{NH}_{3}$ exit with dissociation of $\mathrm{NH}_{4}{ }^{+}$and cellular retention of $\mathrm{H}^{+}$ (Fig. 2A). In the absence of $\mathrm{Na}^{+}$the cytosolic $\mathrm{pH}$ remained acidic, an observation pointing to the absence of appreciable $\mathrm{Na}^{+}$-independent $\mathrm{H}^{+}$extruding transport systems. In the absence of EA, the subsequent addition of $\mathrm{Na}^{+}$was followed by rapid cytosolic realkalinization, an 
Fig. 1. Effect of Ellagic acid (EA) on NHE1 isoform transcript levels and protein levels. A. Arithmetic means \pm SEM $(n=8)$ of NHE1 transcript levels from Ishikawa cells exposed for 48 hours without (control, black bar) or with EA (grey bar; $20 \mu \mathrm{M}$ ).

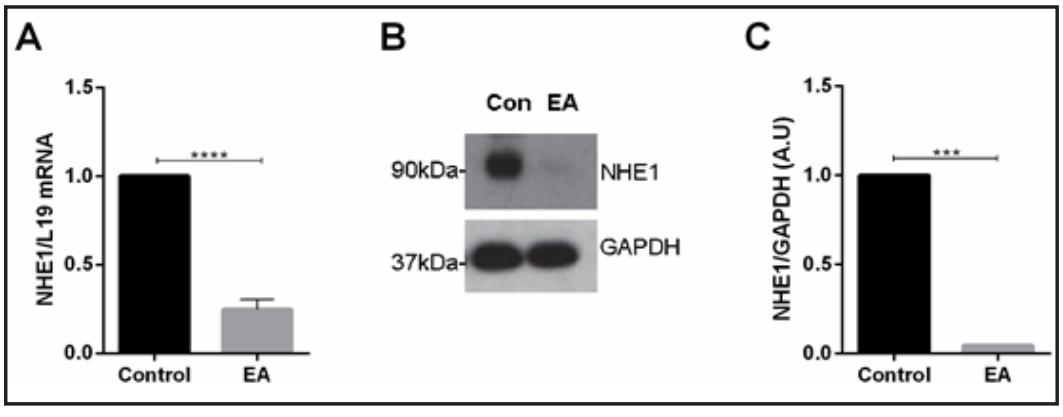
L19 was used as a housekeeping control. **** $(P<0.0001)$ indicates statistically significant difference from untreated cells. B. Original Western blot of NHE1 and GAPDH protein levels from Ishikawa cells with or without a 48 hour treatment with EA $(20 \mu \mathrm{M})$. GAPDH was used as a loading control. C. Arithmetic means \pm SEM $(\mathrm{n}=3)$ of the NHE1/GAPDH protein abundance ratios in cell lysate from Ishikawa cells exposed for 48 hours without (control, black bar) or with EA (grey bar; $20 \mu \mathrm{M})$. $^{* * *}(P<0.001)$ indicates statistically significant difference from untreated cells.

Fig. 2. Effect of Ellagic acid (EA) on pHi and $\mathrm{Na}^{+}$/ $\mathrm{H}^{+}$exchanger activity in Ishikawa cells. A. Original tracings showing alterations of cytosolic $\mathrm{pH}\left(\mathrm{pH}_{\mathrm{i}}\right)$ in Ishikawa cells prior to, during and following an ammonium pulse. To load the cells with $\mathrm{H}^{+}, 20 \mathrm{mM}$ $\mathrm{NH}_{4} \mathrm{Cl}$ was added and $\mathrm{Na}^{+}$ removed (replaced by NMDG) in a first step (see bars below each original tracing), $\mathrm{NH}_{4} \mathrm{Cl}$ removed in a second step, $\mathrm{Na}^{+}$added in a third step and ni-



B

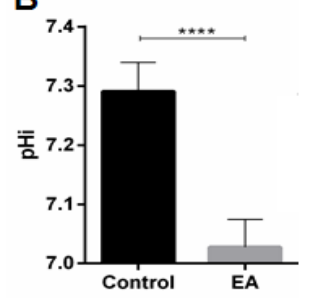

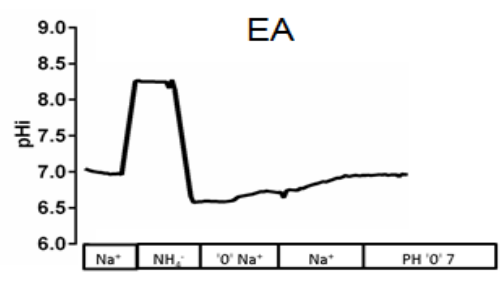

C



gericin $\left(\mathrm{pH}_{\mathrm{o}} 7.0\right)$ applied in a fourth step to calibrate each individual experiment. B. Arithmetic means \pm SEM ( $\mathrm{n}=8$ independent experiments) of cytosolic $\mathrm{pH}$ prior to the ammonium pulse $\left(\mathrm{pH}_{\mathrm{i}}\right)$ in Ishikawa cells exposed for 48 hours without (control, black bar) or with EA, (grey bar; $20 \mu \mathrm{M}$ ). ${ }^{* * * *}$ indicates statistically significant difference $(P<0.0001)$. C. Arithmetic means \pm SEM $\left(\mathrm{n}=8\right.$ independent experiments) of $\mathrm{Na}^{+}$-dependent recovery of cytosolic $\mathrm{pH}(\Delta \mathrm{pH} / \mathrm{min})$ reflecting $\mathrm{Na}^{+} / \mathrm{H}^{+}$exchanger activity in Ishikawa cells exposed for 48 hours without (control, black bar) or with EA (grey bar; $20 \mu \mathrm{M}$ ). ${ }^{* *}$ indicates statistically significant difference $(P<0.01)$.

observation pointing to $\mathrm{Na}^{+} / \mathrm{H}^{+}$exchanger activity. As illustrated in Fig. 2C, the treatment with EA was followed by a significant decrease of $\mathrm{Na}^{+} / \mathrm{H}^{+}$exchanger activity.

According to previous observations oxidative stress may affect expression of NHE1 [17]. Thus, we measured ROS abundance using flow cytometry. As illustrated in Fig. 3A,B ROS was significantly down-regulated in EA treated cells.

$\mathrm{Na}^{+} / \mathrm{H}^{+}$exchanger activity participates in the orchestration of cell volume regulation [18]. Thus, cell volume was estimated from forward scatter determined by flow cytometry. According to the forward scatter, cell volume was reduced in EA treated cells (Fig. 3C,D)

The cytosolic acidification following EA $(20 \mu \mathrm{M})$ treatment was expected to impact on glycolysis. As alterations of glucose consumption by glycolysis were expected to be paralleled by the respective alterations of glucose uptake, the cellular glucose uptake was estimated from 2-NBD-glucose uptake determined by flow cytometry. As shown in Fig. 4A, a 48 hours 


\section{Cellular Physiology Cell Physiol Biochem 2017;41:2374-2382 \begin{tabular}{l|l} 
DOI: 10.1159/000475655 & and Biochemistry 2017 The Author(s). Published by S. Karger AG, Basel \\
wublished &
\end{tabular}

Fig. 3. Effect of Ellagic acid (EA) on ROS production and cell volume in Ishikawa cells. A. Representative original FACS histograms of ROS in Ishikawa cells exposed for 48 hours without (control, dark grey) or with EA (light grey; $20 \mu \mathrm{M}$ ). B. Arithmetic means \pm SEM $(n=12$ independent experiments) of ROS (DCFDA) (Geometric Mean Fluorescence [MFI]) of Ishikawa cells exposed for 48 hours without (control, black bar) or with (EA, grey bar) EA $(20 \mu \mathrm{M})$. C. Representative original FACS histograms of cell volume in Ishikawa cells exposed for 48 hours without (control, dark grey) or with EA (light grey; $20 \mu \mathrm{M})$. D. Arithmetic means \pm SEM ( $\mathrm{n}=$ 12 independent experiments) of forward scatter (Geometric Mean Fluorescence [MFI] intensity of Ishikawa cells) exposed for 48 hours without (control, black bar) or with EA (grey bar; $20 \mu \mathrm{M}) . *(P<0.05)$, $* * *(p<0.001)$ indicates statistically significant difference from untreated cells


B

D
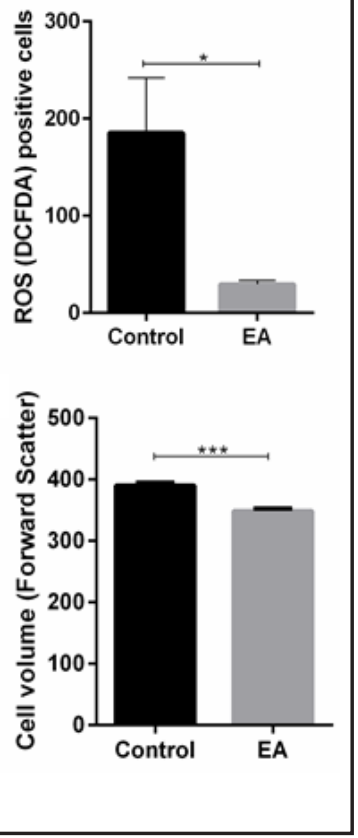

Fig. 4. Effect of Ellagic acid (EA) on glucose uptake and lactate concentration in the supernatant of Ishikawa cells. A. Arithmetic means \pm SEM $(n=8)$ of the glucose uptake (Geometric Mean Fluorescence [MFI] intensity measured by 2-NBDG dye by FACS) without (control, black bar) or with prior 48 hour EA $(20 \mu \mathrm{M})$ treatment (grey bar). ${ }^{* *}(P<0.01)$ indicates statistically significant difference from untreated cells. B. Arithmetic means \pm SEM $(n=4)$ of the lactate concentrations in the supernatant of Ishikawa cells exposed for 48 hours without (control, black bar) or with EA (grey bar; $20 \mu \mathrm{M}){ }^{*}(P<0.05)$ indicates statistically significant difference from untreated cells.

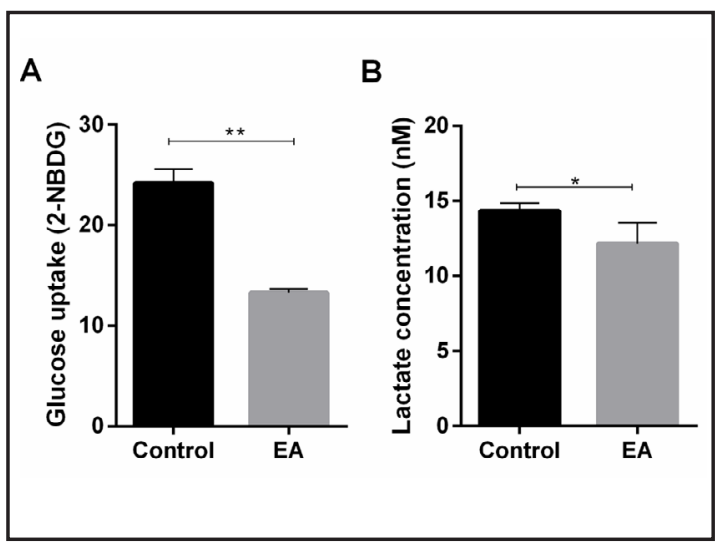

incubation of Ishikawa cells in the presence of EA $(20 \mu \mathrm{M})$ was followed by a significant decrease of cellular glucose uptake.

Alterations of glycolytic flux are further expected to impact on alterations of lactate concentrations determined in the supernatant of Ishikawa cells following a 48 hour incubation in the absence or presence of EA. As illustrated in Fig. 4B, a 48 hour incubation of Ishikawa cells in the presence of EA $(20 \mu \mathrm{M})$ was followed by a significant decrease of lactate concentration in the supernatant.

\section{Discussion}

The present study uncovers a novel and powerful effect of Ellagic acid (EA) on $\mathrm{Na}^{+} / \mathrm{H}^{+}$ exchanger NHE1 expression and activity, which in turn impacts on cytosolic $\mathrm{pH}$ regulation, 
cell volume and glycolytic flux of Ishikawa cells. Treatment with EA is followed by a significant decline of NHE1 transcript levels, NHE1 protein abundance, and $\mathrm{Na}^{+} / \mathrm{H}^{+}$exchanger activity.

The down-regulation of $\mathrm{Na}^{+} / \mathrm{H}^{+}$exchanger activity following EA treatment prevented $\mathrm{Na}^{+} / \mathrm{H}^{+}$exchanger mediated extrusion of $\mathrm{H}^{+}$following cytosolic acidification and thus contributed to the maintenance of an acidic cytosolic $\mathrm{pHi}$. The present observations do, however, not rule out that cytosolic acidification is due to dysregulation of additional $\mathrm{H}^{+}$ extruding transport proteins following EA treatment. Additional $\mathrm{H}^{+}$extruding carriers in tumor cells include $\mathrm{Na}^{+}$coupled bicarbonate cotransporters [16] and lactate or monocarboxylate transporters $[13,16]$, the latter extruding both, lactate and $\mathrm{H}^{+}[26]$. $\mathrm{The}^{\mathrm{N}} \mathrm{a}^{+} / \mathrm{H}^{+}$exchanger activity is, however, highly sensitive to cytosolic $\mathrm{pH}$ and is strongly stimulated by cytosolic acidification [27]. The down-regulation of $\mathrm{Na}^{+} / \mathrm{H}^{+}$exchanger activity precludes stimulation of $\mathrm{Na}^{+} / \mathrm{H}^{+}$exchanger activity following cytosolic acidification and is thus a prerequisite for the down-regulation of cytosolic $\mathrm{pH}$ following EA treatment.

The present observations reveal that EA decreases reactive oxygen species. NHE1 expression and $\mathrm{Na}^{+} / \mathrm{H}^{+}$exchanger activity are highly sensitive to oxidative stress $[17,21]$. $\mathrm{Na}^{+} / \mathrm{H}^{+}$exchanger activity in turn impacts on NADPH oxidase activation and generation of reactive oxygen species [17].

Cellular functions highly sensitive to cytosolic pH further include glycolysis [15]. As the $\mathrm{pK}$ of lactate is below 4 [28], the acid is fully dissociated at the prevailing cytosolic $\mathrm{pH}$ and thus glycolysis is paralleled by cellular formation of $\mathrm{H}^{+}$. In order to accomplish their high rates of glycolysis $[13,14]$ tumor cells up-regulate $\mathrm{H}^{+}$extrusion. Cytosolic acidification due to malfunction of $\mathrm{Na}^{+} / \mathrm{H}^{+}$exchangers and/or other $\mathrm{H}^{+}$extruding transport proteins turns off glycolysis [15]. The sensitivity of glycolysis to cytosolic acidification is an important safeguard of cells [15], as it avoids continued formation of lactate and $\mathrm{H}^{+}$if the cells are unable to dispose the $\mathrm{H}^{+}$produced by glycolysis. By the same token the inhibition of glycolysis by cytosolic acidification disrupts the major energy source of tumor cells $[13,14]$.

Maintenance of alkaline cytosolic $\mathrm{pH}$ is thus decisive for the survival of tumor cells [29-31]. Inhibition of $\mathrm{Na}^{+} / \mathrm{H}^{+}$exchanger and cytosolic acidification parallels apoptosis [32], whereby cytosolic acidification fosters the activation of caspases [33]. Accordingly, the observed cytosolic acidification may contribute to the known stimulation of apoptosis by EA [34, 35].

Beyond its effect on cytosolic $\mathrm{pH}, \mathrm{Na}^{+} / \mathrm{H}^{+}$exchanger activity participates in the regulation of cell volume, which involves parallel activity of $\mathrm{Na}^{+} / \mathrm{H}^{+}$exchanger and $\mathrm{Cl}^{-} / \mathrm{HCO}_{3}{ }^{-}$exchanger $[36,37]$. The carriers mediate the entry of $\mathrm{NaCl}$ in exchange for $\mathrm{H}^{+}$and $\mathrm{HCO}_{3}^{-}$, which are replenished from $\mathrm{CO}_{2}$ and are thus not osmotically relevant [36, 37]. Timely increase of cell volume is a prerequisite for cell proliferation [36, 37] and stimulation of cell proliferation is paralleled by a shift of the $\mathrm{Na}^{+} / \mathrm{H}^{+}$exchanger cell volume regulatory set point to larger volumes [37].

In conclusion, the present study demonstrates that EA down-regulates expression and function of the $\mathrm{Na}^{+} / \mathrm{H}^{+}$exchanger, decreases cytosolic acidification with subsequent impairment of glycolysis. Those effects may well contribute to the anti-proliferative effects of EA.

\section{Acknowledgements}

This work was supported by grants from Deutsche Forschungsgemeinschaft (La 315/15) and Open Access Publishing Fund of Tuebingen University, as well as the EMBO Long Term Postdoctoral fellowship (ATLF 20-2013 to M.S.S), the Fortüne Grant (24260-0 to M.S.S) and the Institutional Strategy of the University of Tübingen (Deutsche Forschungsgemeinschaft, ZUK 63) to M.S.S. We are also thankful to the Arab Republic of Egypt (Egytian Culture Affairs \& Missions Sector) Scholarship to K.A-N. The authors gratefully acknowledge the meticulous preparation of the manuscript by Tanja Loch and Lejla Subasic. 


\section{Cellular Physiology Cell Physiol Biochem 2017;41:2374-2382 and Biochemistry Published onlIne: April 27, $2017 \quad \begin{aligned} & \text { DOI: 10.1159/000475655 } \\ & \begin{array}{l}\text { c } 2017 \text { The Author(s). Published by S. Karger AG, Basel } \\ \text { ww.karger.com/cpb }\end{array}\end{aligned}$ \\ Abdelazeem et al.: Effect of Ellagic Acid on Endometrial Cancer Cells}

\section{Disclosure Statement}

The authors have no competing interests to declare.

\section{References}

1 Di Cristofano A, Ellenson LH: Endometrial carcinoma. Annu Rev Pathol 2007;2:57-85.

$\rightarrow 2$ Murali R, Soslow RA, Weigelt B: Classification of endometrial carcinoma: more than two types. Lancet Oncol 2014;15:e268-278.

3 Ceci C, Tentori L, Atzori MG, Lacal PM, Bonanno E, Scimeca M, Cicconi R, Mattei M, de Martino MG, Vespasiani G, Miano R, Graziani G: Ellagic Acid Inhibits Bladder Cancer Invasiveness and In Vivo Tumor Growth. Nutrients 2016;8:

- 4 Nunez-Sanchez MA, Karmokar A, Gonzalez-Sarrias A, Garcia-Villalba R, Tomas-Barberan FA, Garcia-Conesa MT, Brown K, Espin JC: In vivo relevant mixed urolithins and ellagic acid inhibit phenotypic and molecular colon cancer stem cell features: A new potentiality for ellagitannin metabolites against cancer. Food Chem Toxicol 2016;92:8-16.

5 Heber D: Multitargeted therapy of cancer by ellagitannins. Cancer Lett 2008;269:262-268.

6 Zhang HM, Zhao L, Li H, Xu H, Chen WW, Tao L: Research progress on the anticarcinogenic actions and mechanisms of ellagic acid. Cancer Biol Med 2014;11:92-100.

7 Bell C, Hawthorne S: Ellagic acid, pomegranate and prostate cancer -- a mini review. J Pharm Pharmacol 2008;60:139-144.

-8 Vicinanza R, Zhang Y, Henning SM, Heber D: Pomegranate Juice Metabolites, Ellagic Acid and Urolithin A, Synergistically Inhibit Androgen-Independent Prostate Cancer Cell Growth via Distinct Effects on Cell Cycle Control and Apoptosis. Evid Based Complement Alternat Med 2013;2013:247504.

-9 Sarkaki A, Farbood Y, Dolatshahi M, Mansouri SM, Khodadadi A: Neuroprotective Effects of Ellagic Acid in a Rat Model of Parkinson's Disease. Acta Med Iran 2016;54:494-502.

10 Reddy BU, Mullick R, Kumar A, Sudha G, Srinivasan N, Das S: Small molecule inhibitors of HCV replication from pomegranate. Sci Rep 2014;4:5411.

11 Derosa G, Maffioli P, Sahebkar A: Ellagic Acid and Its Role in Chronic Diseases. Adv Exp Med Biol 2016;928:473-479.

12 Garcia-Nino WR, Zazueta C: Ellagic acid: Pharmacological activities and molecular mechanisms involved in liver protection. Pharmacol Res 2015;97:84-103.

13 Parks SK, Chiche J, Pouyssegur J: Disrupting proton dynamics and energy metabolism for cancer therapy. Nat Rev Cancer 2013;13:611-623.

14 Reshkin SJ, Greco MR, Cardone RA: Role of pHi, and proton transporters in oncogene-driven neoplastic transformation. Philos Trans R Soc Lond B Biol Sci 2014;369:20130100.

15 Boiteux A, Hess B: Design of glycolysis. Philos Trans R Soc Lond B Biol Sci 1981;293:5-22.

-16 Kong SC, Gianuzzo A, Novak I, Pedersen SF: Acid-base transport in pancreatic cancer: Molecular mechanisms and clinical potential. Biochem Cell Biol 2014;92:449-459.

17 De Vito P: The sodium/hydrogen exchanger: a possible mediator of immunity. Cell Immunol 2006;240:6985.

18 Lang F: Mechanisms and significance of cell volume regulation. J Am Coll Nutr 2007;26:613S-623S.

-19Voelkl J, Pasham V, Ahmed MS, Walker B, Szteyn K, Kuhl D, Metzler B, Alesutan I, Lang F: Sgk1-dependent stimulation of cardiac Na+/H+ exchanger Nhe1 by dexamethasone. Cell Physiol Biochem 2013;32:25-38.

20 Singh Y, Zhou Y, Shi X, Zhang S, Umbach AT, Salker MS, Lang KS, Lang F: Alkaline Cytosolic pH and High Sodium Hydrogen Exchanger 1 (NHE1) Activity in Th9 Cells. J Biol Chem 2016;291:23662-23671.

21 Zhou Y, Shi X, Chen H, Zhang S, Salker MS, Mack AF, Foller M, Mak TW, Singh Y, Lang F: DJ-1/Park7 Sensitive $\mathrm{Na}+$ /H+ Exchanger 1 (NHE1) in CD4+ T Cells. J Cell Physiol 2016;10.1002/jcp.25516

22 Salker MS, Zhou Y, Singh Y, Brosens J, Lang F: LeftyA sensitive cytosolic pH regulation and glycolytic flux in Ishikawa human endometrial cancer cells. Biochem Biophys Res Commun 2015;460:845-849.

23 Waisbren SJ, Geibel J, Boron WF, Modlin IM: Luminal perfusion of isolated gastric glands. Am J Physiol 1994;266:C1013-1027.

24 Roos A, Boron WF: Intracellular pH. Physiol Rev 1981;61:296-434. 


\section{Cellular Physiology Cell Physiol Biochem 2017;41:2374-2382

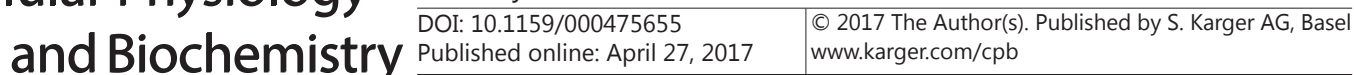 \\ Published onlıne: April 27, 2017}

25 Boyarsky G, Ganz MB, Sterzel RB, Boron WF: pH regulation in single glomerular mesangial cells. I. Acid extrusion in absence and presence of HCO3. Am J Physiol 1988;255:C844-856.

26 Adijanto J, Philp NJ: The SLC16A family of monocarboxylate transporters (MCTs)--physiology and function in cellular metabolism, pH homeostasis, and fluid transport. Curr Top Membr 2012;70:275-311.

-27 Wakabayashi S, Shigekawa M, Pouyssegur J: Molecular physiology of vertebrate $\mathrm{Na}+\mathrm{H}+$ exchangers. Physiol Rev 1997;77:51-74.

28 Martin LR, Mezyk SP, Mincher BJ: Determination of arrhenius and thermodynamic parameters for the aqueous reaction of the hydroxyl radical with lactic acid. J Phys Chem A 2009;113:141-145.

29 Andersen AP, Moreira JM, Pedersen SF: Interactions of ion transporters and channels with cancer cell metabolism and the tumour microenvironment. Philos Trans R Soc Lond B Biol Sci 2014;369:20130098. Damaghi M, Wojtkowiak JW, Gillies RJ: pH sensing and regulation in cancer. Front Physiol 2013;4:370.

31 Swietach P, Vaughan-Jones RD, Harris AL, Hulikova A: The chemistry, physiology and pathology of pH in cancer. Philos Trans R Soc Lond B Biol Sci 2014;369:20130099.

-32 Lang F, Madlung J, Bock J, Lukewille U, Kaltenbach S, Lang KS, Belka C, Wagner CA, Lang HJ, Gulbins E, Lepple-Wienhues A: Inhibition of Jurkat-T-lymphocyte Na+/H+-exchanger by CD95(Fas/Apo-1)-receptor stimulation. Pflugers Arch 2000;440:902-907.

-33 Lupescu A, Geiger C, Zahir N, Aberle S, Lang PA, Kramer S, Wesselborg S, Kandolf R, Foller M, Lang F, Bock CT: Inhibition of $\mathrm{Na}+\mathrm{H}+$ exchanger activity by parvovirus B19 protein NS1. Cell Physiol Biochem 2009;23:211-220.

-34 Postovit LM, Margaryan NV, Seftor EA, Kirschmann DA, Lipavsky A, Wheaton WW, Abbott DE, Seftor RE, Hendrix MJ: Human embryonic stem cell microenvironment suppresses the tumorigenic phenotype of aggressive cancer cells. Proc Natl Acad Sci U S A 2008;105:4329-4334.

-35 Sun G, Shi L, Li M, Jiang N, Fu L, Guo J: Lefty inhibits glioma growth by suppressing Nodal-activated Smad and ERK1/2 pathways. J Neurol Sci 2014;10.1016/j.jns.2014.09.034

36 Hoffmann EK, Lambert IH, Pedersen SF: Physiology of cell volume regulation in vertebrates. Physiol Rev 2009;89:193-277.

37 Lang F, Busch GL, Ritter M, Volkl H, Waldegger S, Gulbins E, Haussinger D: Functional significance of cell volume regulatory mechanisms. Physiol Rev 1998;78:247-306. 